\title{
Design of a Smart Visiting Service Management System for Personal Information Collection in Order to Integrate Tourism Management into an Isolated Island
}

\author{
Xiao Teng and Zhenjiang Shen * (D) \\ Graduate School of Natural Science \& technology, Kanazawa University, Kanazawa 920-1192, Japan; \\ tang.xiaoruy@gmail.com \\ * Correspondence: shenzhe@se.kanazawa-u.ac.jp; Tel.: +81-762344650
}

Received: 10 July 2020; Accepted: 12 September 2020; Published: 16 September 2020

check for updates

\begin{abstract}
Personal information is collected by different smart services and integrated into one big data database, in contemplation of the smart visiting service management on an isolated island. Thereby, the information about a certain person's activities is possibly managed by one database, and smart services are conveniently provided for the users, at the same time protecting their personal information. In a case study on Huangguan Island, personal information was collected in an urban space by different smart service providers, for various business purposes. The personal information was collected on the isolated island not only via personal mobile devices, but also from smart facilities arranged by the building and transportation means. As opposed to the previous research reports on tourism information services for smart tourism using big data analysis and processing, we proposed a smart visiting service management system in order to integrate tourism services into an isolated island. After reviewing the proposed smart visiting service management system in the case study practice, the principles of personal information collection were defined in this work.
\end{abstract}

Keywords: infrastructure monitoring; personalized smart service; personal information collection; big data database; smart tourism

\section{Introduction}

Presently, smart city constructions have been implemented in many cities around the world as pilot urban development, however, the issue of cyber security and privacy of big data in cyber-physical-social systems is rising too [1]. Big data is the sensor-based product of Information Communication Technology (ICT) [2] collected from all smart devices and Internet of Things (IoT) in urban and building spaces, that has the ability to change the lifestyle of a human, and also cause a significant effect on the usage of urban and building spaces [3]. Thus, big data and its smart services will create a new trend of designing smart buildings in the near future, due to the providing of the new smart services in daily life to people based on their personal information [4]. In this paper, we consider the smart city project on Huangguan Island as the case study for analyzing the kinds of personal information used, and how the relatively big data standing for individual activities can be synergized in the system design of smart visiting service management systems.

Li et al. [5] determined the definition of smart tourism as an individual tourist support system within the context of information services and an all-encompassing technology. In this case study, the current approach to the development of the smart visiting service management system (SVSMS) is discussed to identify the principles of personal information collection, and if it is possible to synergize 
the personal data in an integrated database system, where personalized smart services can specify the personal information between each other on the isolated island.

From a viewpoint of big data usage in smart management services, personal information collected by many smart devices and IoT sensors in urban spaces is very helpful for the urban management [6]. Big data analytics have been widely implemented in marketing and business innovation processes, which also create business value at a larger scale [7]. Urban planning and design will be changed greatly by the application of big data, as a result of the urban management services' ability to be improved in many aspects by using that data [8]. Andreani et al. [9] offers an alternative perspective to a design-driven and human-centered smart city approach. Therefore, even though ICT has provided new data sources for the urban management, integrating these new data sources for providing smart services to planning and designing with collected personal information still remains a challenge. Thus, we attempt to find how the currently collected personal information in the case study project can improve or limit the capacity of the smart visiting service management system (SVSMS).

From a viewpoint of personal information protection, smart tourism includes privacy and data protection; its challenges have been reviewed in some research reports [10]. Kontogianni and Alepis [10] introduce the concept of smart tourism system, and reach to a conclusion that all the technologies, such as the augmented reality, social media, image recognition, wearables of all kinds, smart vehicles, sensors, etc., are still constantly evolving, so the smart tourism sector still has a long way to go. Researchers attempt to take advantage of the constantly emerging technologies with the purpose of establishing the foundations of the smart tourism sector. In regard to the innovative ideas in our work, we propose a smart visiting service management system using virtual reality that integrates all kinds of smart devices and provides diversified data sources for tourism management.

Lin et al. [11] investigated the law system for protecting the usage of personal information, due to the big data collected from mobile devices and sensors in different countries, which are very valuable for business activities in urban spaces. As for the education, Teng et al. [12] concluded that student information is necessary for management of all education activities, and if all students' activities and their information can be stored in a cloud system, the convenience of education management will be significantly improved. From the view of personal information usage disputed in Teng et al. [11,12], if an interaction between different smart service systems can be done in an integrated cloud database of SVSM, real-time feedback to staff and users in our case study island will greatly improve smart visiting services.

\subsection{Smart City Management and Personal Information}

With the informatization and the development of globalization in the recent years, local government also aims for higher efficient urban management and ICT equipment is applied during the process of urbanization [13]. The flexible application of smart city management services using ICT will become the strategic development goal worldwide. Thus, higher quality of urban management is a result of the application of the advantages of ICT. On the other hand, smart services provided for users are based on personal information collected by smart infrastructure under management of different personalized smart service providers.

There are also some reports related to cultural and political tradition to personal information in the literature. Das [14] argued that the smart city management ways will be different based on various urban governance systems, infrastructure monitoring, and smart services. Wang et al. [15] investigated the issue of consumer intentions to disclose personal information via mobile applications.

As mentioned above, it is important to review the efficient usage of the personal information, while protecting personal information, for running a smart city management system. From our perspective, the new form of city management using ICT is composed of all kinds of systems related to smart infrastructure and its devices based on the smart city construction. Personalized smart services can only be provided by connecting personal information to the smart devices. 


\subsection{Big Data by Infrastructure Monitoring System}

In the present study, the data, big data in particular, collected from urban spaces, is the personal data of human activities and monitoring data of smart infrastructure. There are two types of big data; one type is monitored from infrastructure and its devices, and another type is personal information collected from smart devices observing human activities. Even though it is only possible to provide smart services based on the functions of smart infrastructure and its devices, smart infrastructure cannot produce personal information. Considering the smart city management for personalized smart services as the goal, a smart city management system can be divided as an infrastructure monitoring system and a smart service system.

The concept of smart cities has been evolving for more than 20 years [16]. The Internet of Things (IoT) is the network of devices monitoring the connected infrastructure and communicating with each other without requiring human-to-human or human-to-computer interaction. In order to provide smart services to the smart city management system, Brdys [17] introduces a critical infrastructure system as an infrastructure monitoring tool; the smart devices using ICT are indispensable equipment for monitoring. Monitoring the situation of smart infrastructure is a vital aspect of smart city management [18], which is essential before starting to provide smart services to the users. Moreover, different scales of urban spaces will have diverse systems of architecture in scale. For example, due to the size of collected data, the data center [19] will be different.

\subsection{Personal Information of a Smart Service System}

The information included in an ID number does not only include merely personal information, but also specific personal information that can be defined as non-public information and is not allowed to be opened. Therefore, the users who have provided their ID information have higher risks of being disclosed, so, management should follow strict protection regulations towards their personal information. If there are limitations for providing specific personal information by law, even though the person himself or herself agrees, the information still cannot be transferred, exceeding the application scope. Accordingly, the information must be applied cautiously, if personal information is involved in the smart service procedures in the case study on the island.

As reported by Kim et al. [20], there is a lot of personal information in a city, such as the following lists: visitor list, staff lists, locations of the visiting places, and related documents, such as health status, telephone numbers, and so on. The personal data is collected from the people who are willing to put their personal information on personal cloud-based storage applications in order to use relative services [21]. The direct effects on perceived benefits and risks induce the ultimate intention to disclose personal information, due to the convenience of using mobile apps [15]. From the view of personal information protection, the consent of a person and the limitations of providing personal information concerning a specific person are the critical conditions for smart services, if the personal information can be provided to the third party that is managing a respectively smart service system [22].

In this paper, the system framework of SVSMS is discussed in order to fully use big data in the urban study of Huangguan Island, and the system design is divided into infrastructure monitoring system and smart service system. Therefore, a comprehensive review on personal information for smart visiting services is conducted, and the differences between non-public personal information, public personal information, and their usages are clarified, according to the personalized smart visiting services in the case study of the SVSMS of Huangguan Island.

\section{Theoretical Concept and Methodology}

Generally speaking, the application of big data is changing human lifestyle and city management worldwide, and, reversely, physical urban and building environments will be necessarily changed to match the style of smart life and business spaces using ICT. As mentioned above, in the field of urban planning and design, urban management is more and more dependent on smart city management 
system. The big data of human activities stored from ICT, and plenty of personal information, is useful in this case. With the purpose of improving the quality of visiting services management in the case study area, the application of personal information is indispensable in the system design, and we are trying to figure out the principle of employment of the personal information in this project.

Firstly, smart visiting service management includes management for physical infrastructure facilities and human activity. Thus, we develop the SVSMS in Huangguan as two systems, namely the smart services system (SSS) and the infrastructure monitoring system (IMS). Accordingly, the infrastructure monitoring system is not the system for handling the personal information database. Considering the personal information collection, we can focus on the smart service system. Based on the personal data, if it is possible to identify an individual person, the information can be divided into non-public personal information and public personal information. Public personal information can be disclosed and shared by different smart service providers.

Secondly, we analyze the personal data that is being collected by the smart services system for managing purposes, as well as the ID as a form of personal information collected from different smart devices, that is linking all databases in different providers. Finally, the principles of personal information collection can be discovered, while protecting non-public personal information by reviewing the application of the SVSMS on Huangguan Island. In this study, we focus on the application of personal information to the system design; hereby, the data collection and analysis are not organized for further discussion in the following sections.

\section{Case Study on Huangguan Island}

Smart city management systems are now popular in the world of managing cities; they can increase the capabilities of local government with the help of ICT. On Huangguan Island, the SVSMS is composed of two databases; one is the physical information database, which includes the environment data and infrastructure data; the other is the human information database, including personal data collected from all smart services, such as mobile devices, transportation cards, personal identification systems, and cameras monitoring human activities on the island.

Huangguan Island is an isolated island in Fujian Province, China. There are no original residents there. The island was developed by the Longshen Group in 2016. The island is located close to Dongbi Island, where it can take people one hour to get to Fuqing City, which belongs to the Fuzhou New District, as demonstrated in Figure 1. Huangguan Island is located near the Fuzhou New District, and belongs to the Fuzhou-Putian-Ningde Metropolitan Area. It is based within the 0.5-hour travel circle of Fuqing, and the 1-hour travel circle of Fuzhou. The capacity of visiting services is fifteen $\log$ houses for 60 persons or 15 families, and the main hotel for 100 guests. In total, there are 20 staff members for all of the office work on the island. Thus, it is a small database for management.
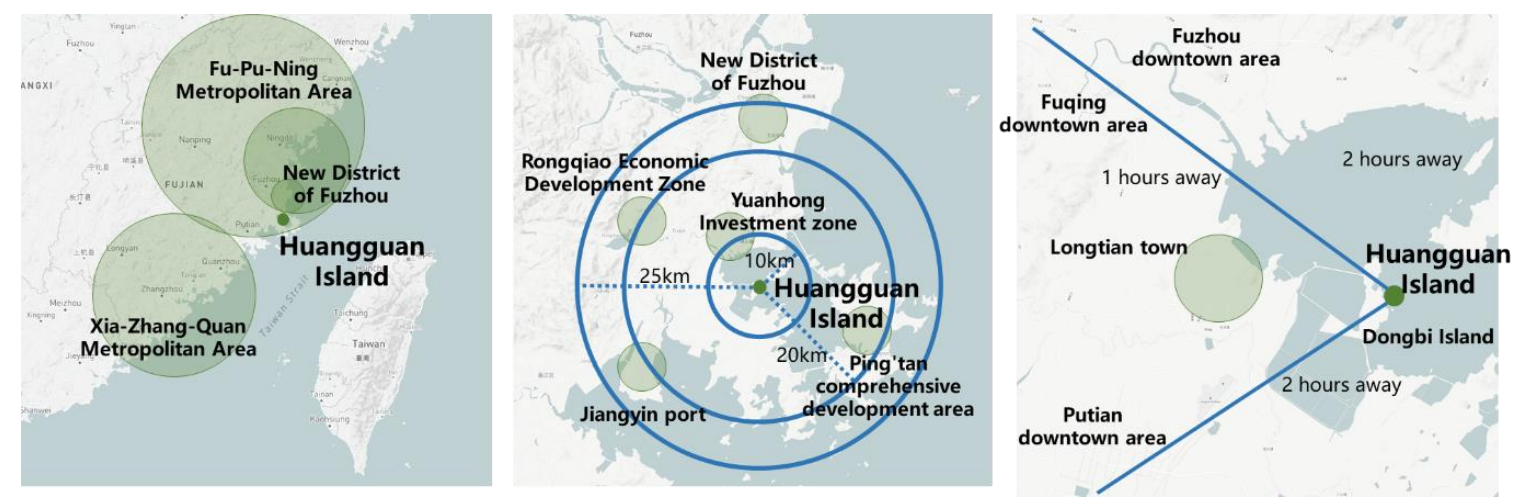

Figure 1. Location of Huangguan Island. 
There are two systems proposed in the Huangguan SVSMS: the smart services system and the infrastructure monitoring system, as indicated in Figure 2. Therefore, the smart service system is used for the human information database containing personal information and data, while the infrastructure monitoring system is used for the physical information database containing the environment data and the infrastructure data. In this research, we focus on the understanding of the ways to deal with personal information collected by the SSS for the improvement of visiting management, which is an integrated system with all of the smart services on Huangguan Island.

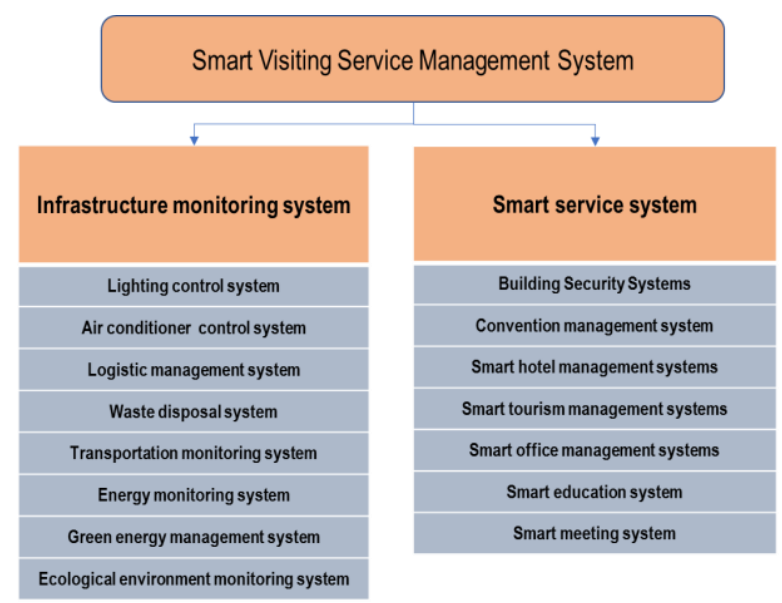

Figure 2. Smart visiting service management in Huangguan.

Hereafter, we explain how the SVSMS is composed of different smart services, how the personal information is collected by those systems, and how that data can be provided in order to support the integrated services on the island.

\subsection{Infrastructure Monitoring System}

The smart infrastructure and smart services are the two main components of the Huangguan SVSMS. The smart infrastructure is presented in Figure 3. The smart data center is designed to employ the unified construction specifications and data exchange standards, with the purpose of ensuring that data resources are properly collected and transmitted. Therefore, the data is smoothly shared between different systems on the island to maintain smart services that are provided by smart infrastructures to visitors, residents, staff, and others on the island.

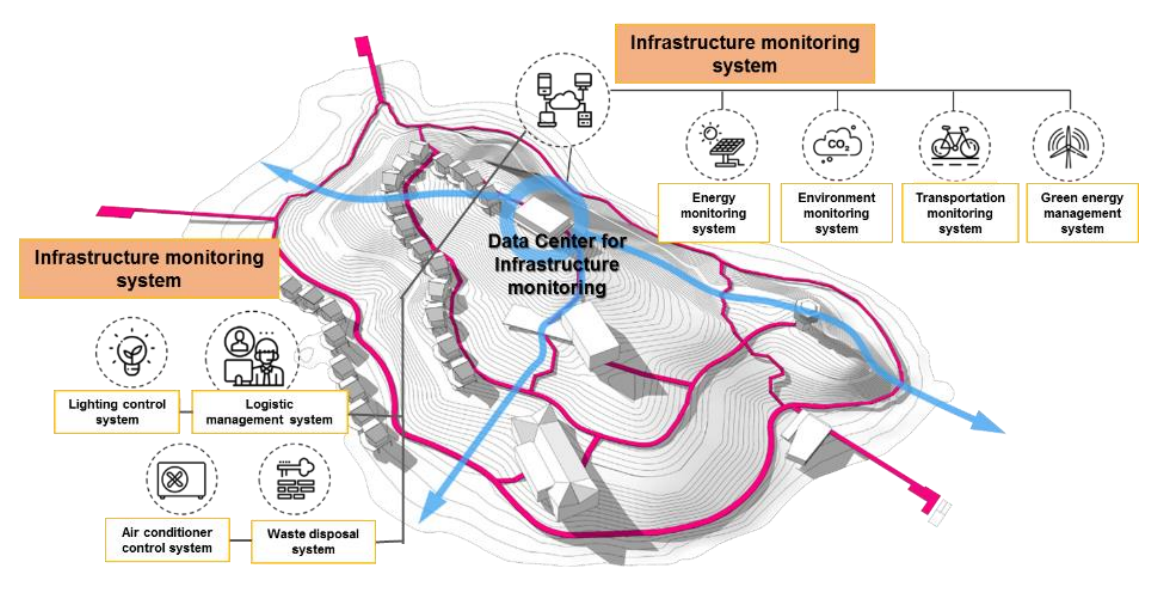

Figure 3. Smart infrastructure in Huangguan. 


\subsection{Personal Information and Smart Service System}

In order to use smart services, the users should be registered in the system. As demonstrated in Table 1, there are seven smart services in the SSS, that contain personal information such as facial recognition, ID, system user ID, bank account information, phone number, address, sex, and age. Table 2 shows the building spaces where smart services systems are installed. Users, who use smart services on Huangguan Island, open their personal information to smart service systems. The personal information registered in the SSS can be shared by different systems for management purposes.

Table 1. Personal information in the smart service system (SSS) proposed on Huangguan Island.

\begin{tabular}{|c|c|c|c|c|c|c|c|}
\hline \multirow[b]{2}{*}{$\begin{array}{c}\text { Smart Service } \\
\text { System }\end{array}$} & \multicolumn{7}{|c|}{ Personal Information } \\
\hline & $\begin{array}{c}\text { Facial } \\
\text { Recognition }\end{array}$ & $\begin{array}{l}\text { User } \\
\text { ID }\end{array}$ & ID & $\begin{array}{c}\text { Bank } \\
\text { Account } \\
\text { Information }\end{array}$ & $\begin{array}{l}\text { Phone } \\
\text { Number }\end{array}$ & Address & $\begin{array}{c}\text { Sex and } \\
\text { Age }\end{array}$ \\
\hline $\begin{array}{l}\text { Building security } \\
\text { systems }\end{array}$ & Y & Y & & & & & \\
\hline $\begin{array}{l}\text { Convention } \\
\text { management } \\
\text { system }\end{array}$ & $\mathrm{Y}$ & Y & $\mathrm{Y}$ & & & & \\
\hline $\begin{array}{l}\text { Smart hotel } \\
\text { management } \\
\text { systems }\end{array}$ & Y & & Y & Y & Y & & \\
\hline $\begin{array}{l}\text { Smart tourism } \\
\text { management } \\
\text { systems }\end{array}$ & & Y & & Y & Y & & \\
\hline $\begin{array}{l}\text { Smart office } \\
\text { management } \\
\text { systems }\end{array}$ & Y & Y & & & & & \\
\hline $\begin{array}{c}\text { Smart training } \\
\text { system }\end{array}$ & & Y & & & & & \\
\hline $\begin{array}{l}\text { Smart meeting } \\
\text { system }\end{array}$ & & Y & & & Y & & \\
\hline
\end{tabular}

Table 2. Buildings spaces and the SSS.

\begin{tabular}{cccccccc}
\hline & $\begin{array}{c}\text { Resident } \\
\text { Center }\end{array}$ & $\begin{array}{c}\text { Visitor } \\
\text { Center }\end{array}$ & Hotel & $\begin{array}{c}\text { Innovation } \\
\text { Office }\end{array}$ & $\begin{array}{c}\text { Training } \\
\text { Center }\end{array}$ & $\begin{array}{c}\text { Convention } \\
\text { Center }\end{array}$ & $\begin{array}{c}\text { Conference } \\
\text { Center }\end{array}$ \\
\hline $\begin{array}{c}\text { Building } \\
\text { security systems }\end{array}$ & $\mathrm{Y}$ & $\mathrm{Y}$ & $\mathrm{Y}$ & $\mathrm{Y}$ & $\mathrm{Y}$ & $\mathrm{Y}$ & $\mathrm{Y}$ \\
\hline $\begin{array}{c}\text { Convention } \\
\text { management } \\
\text { system }\end{array}$ & & & & & $\mathrm{Y}$ & \\
\hline $\begin{array}{c}\text { Smart hotel } \\
\text { management } \\
\text { systems }\end{array}$ & $\mathrm{Y}$ & $\mathrm{Y}$ & & & & $\mathrm{Y}$ \\
\hline $\begin{array}{c}\text { Smart tourism } \\
\text { management } \\
\text { systems }\end{array}$ & & & $\mathrm{Y}$ & $\mathrm{Y}$ & $\mathrm{Y}$ & $\mathrm{Y}$ \\
\hline $\begin{array}{c}\text { Smart office } \\
\text { management } \\
\text { systems }\end{array}$ & & $\mathrm{Y}$ & $\mathrm{Y}$ & $\mathrm{Y}$ & $\mathrm{Y}$ \\
\hline $\begin{array}{c}\text { Smart training } \\
\text { system }\end{array}$ & $\mathrm{Y}$ & $\mathrm{Y}$ & $\mathrm{Y}$ & $\mathrm{Y}$ & $\mathrm{Y}$ & $\mathrm{Y}$ \\
\hline $\begin{array}{c}\text { Smart meeting } \\
\text { system }\end{array}$ & & & & & \\
\hline
\end{tabular}




\section{Smart Management Services and Personal Information in the Huangguan SVSMS}

In order to use SVSMS in a suitable way, the collection of personal information and sharing of personal information should provide the diversity of smart services for the visitors of Huangguan Island.

\subsection{Building Spaces and Smart Service Systems in the SVSMS}

As indicated in Table 2, there are seven types of smart services provided in the island; the buildings of the services are installed in the same table.

\subsection{Building Security System and Personal Information}

It is usually necessary to collect personal information for building security management. As demonstrated in Figure 4 and Table 3, we take the building security system as an example for explanation of the relationship between smart services, buildings, and users. Due to the large amount of products used for collecting the personal information, we take wearable hand ring and facial recognition as an example, as indicated in Table 3.

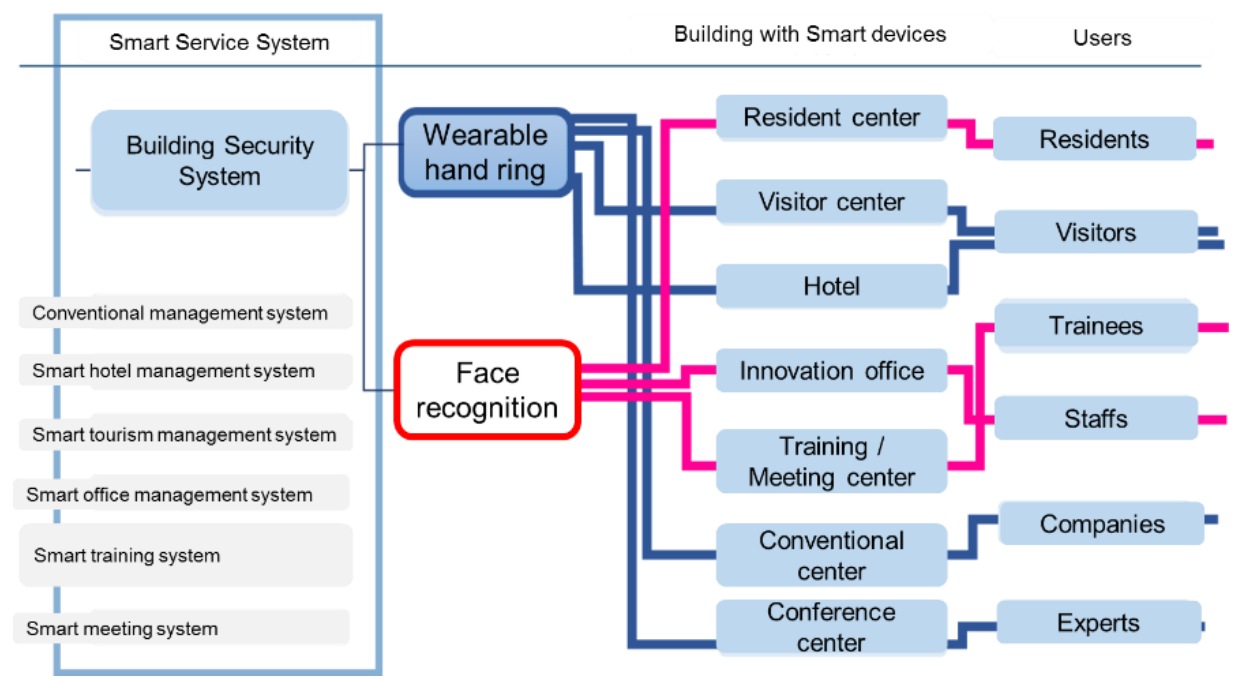

Figure 4. The building security system in the smart visiting service management system (SVSMS).

\subsection{Smart Service System and Personal Information}

In the present work, local public institutions make the laws and regulations for the protection of personal information, generating rules for the objects of personal information, rules for obtaining the personal information, protection and management rules of personal information, and rules for providing personal information to the third parties.

In this section, we did not classify all of the smart devices for collecting personal information in the other smart service systems. There are a lot of smart devices that can be used to collect personal information, such as the wearable hand ring and facial recognition, with the purpose of building a security system, as demonstrated in Table 3 .

In Figure 5 and Table 3, we determine the kinds of smart service systems needed to collect personal information in different buildings from different users. 


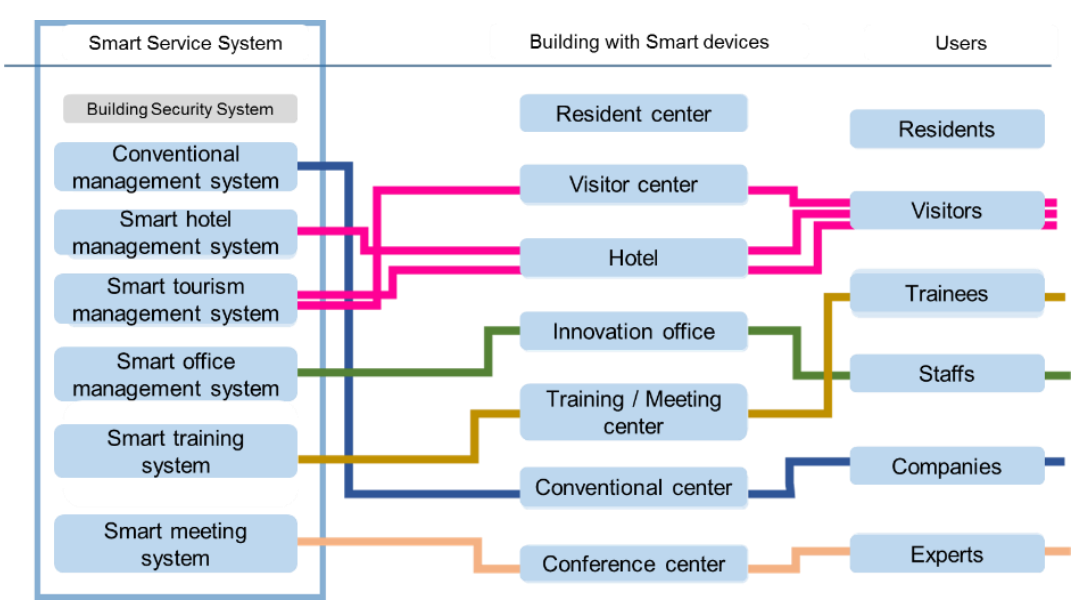

Figure 5. The other smart service system in the SVSMS.

Table 3. Integrated personal information in building spaces with the SSS.

\begin{tabular}{|c|c|c|c|c|c|c|}
\hline \multirow{2}{*}{$\begin{array}{l}\text { Smart Service } \\
\text { System }\end{array}$} & \multirow{2}{*}{ Buildings } & \multicolumn{5}{|c|}{ Smart Service Users } \\
\hline & & Residents & Visitors & Trainees & Staffs & Experts \\
\hline \multirow{2}{*}{$\begin{array}{l}\text { Conventional } \\
\text { management system }\end{array}$} & Convention center & $\mathrm{Y}$ & $\mathrm{Y}$ & & $\mathrm{Y}$ & $\mathrm{Y}$ \\
\hline & Conference center & & $\mathrm{Y}$ & & $\mathrm{Y}$ & $\mathrm{Y}$ \\
\hline \multirow{2}{*}{$\begin{array}{c}\text { Smart hotel } \\
\text { management system }\end{array}$} & Visitor center & & $\mathrm{Y}$ & & $\mathrm{Y}$ & \\
\hline & Hotel & & $\mathrm{Y}$ & & $\mathrm{Y}$ & \\
\hline \multirow{4}{*}{$\begin{array}{l}\text { Smart tourism } \\
\text { management system }\end{array}$} & Visitor center & & $\mathrm{Y}$ & & $\mathrm{Y}$ & \\
\hline & Hotel & & $\mathrm{Y}$ & & $\mathrm{Y}$ & \\
\hline & Convention center & & $\mathrm{Y}$ & & $\mathrm{Y}$ & \\
\hline & Conference center & & $\mathrm{Y}$ & & $\mathrm{Y}$ & \\
\hline \multirow{7}{*}{$\begin{array}{c}\text { Smart office } \\
\text { management system }\end{array}$} & Resident center & $\mathrm{Y}$ & & & $\mathrm{Y}$ & \\
\hline & Visitor center & & $\mathrm{Y}$ & & $\mathrm{Y}$ & \\
\hline & Hotel & & $\mathrm{Y}$ & & $\mathrm{Y}$ & \\
\hline & Innovation office & & & $\mathrm{Y}$ & $\mathrm{Y}$ & \\
\hline & Training center & & & $\mathrm{Y}$ & $\mathrm{Y}$ & \\
\hline & Convention center & $\mathrm{Y}$ & $\mathrm{Y}$ & & $\mathrm{Y}$ & $\mathrm{Y}$ \\
\hline & Conference center & $\mathrm{Y}$ & $\mathrm{Y}$ & & $\mathrm{Y}$ & $\mathrm{Y}$ \\
\hline \multirow{2}{*}{$\begin{array}{l}\text { Smart training } \\
\text { management system }\end{array}$} & Innovation office & $\mathrm{Y}$ & $\mathrm{Y}$ & $\mathrm{Y}$ & $\mathrm{Y}$ & $\mathrm{Y}$ \\
\hline & Training center & $\mathrm{Y}$ & $\mathrm{Y}$ & $\mathrm{Y}$ & $\mathrm{Y}$ & $\mathrm{Y}$ \\
\hline \multirow{7}{*}{ Smart meeting system } & Resident center & $\mathrm{Y}$ & & & $\mathrm{Y}$ & \\
\hline & Visitor center & & $\mathrm{Y}$ & & $\mathrm{Y}$ & \\
\hline & Hotel & & $\mathrm{Y}$ & & $\mathrm{Y}$ & \\
\hline & Innovation office & & & $\mathrm{Y}$ & $\mathrm{Y}$ & $\mathrm{Y}$ \\
\hline & Training center & & & $\mathrm{Y}$ & $\mathrm{Y}$ & $\mathrm{Y}$ \\
\hline & Convention center & & & $\mathrm{Y}$ & $\mathrm{Y}$ & $\mathrm{Y}$ \\
\hline & Conference center & & & $\mathrm{Y}$ & $\mathrm{Y}$ & $\mathrm{Y}$ \\
\hline
\end{tabular}


The personal information collected from all smart service systems could be shared with each system for the visiting management. But for protecting personal information, the kinds of personal information necessary for sharing need to be clarified and kept in the integrated database system.

\section{Integrated Smart Services and Personal Information}

Smart services operated by users are provided by different companies which use the selected service information and user information, including the private personal information. In our case study, the necessary purposes for using personal information in the island project are payment, identification, security checking, and so on. In this research, the management system is developed based on the virtual reality (VR) engine, namely Unity3D, in which the entire workflow, from data acquisition to VR visualization, is designed in detail, with particular emphasis given to the $3 \mathrm{D}$ modelling. Using this kind of system makes it possible to move through the VR environment for interactive visual navigation while exploring VR-modelled landscapes [23,24].

An integrated system for smart services is needed for the visiting management in Huangguan, as shown in Figure 6. Since Huangguan is a small island for tourism, the number of visitors is limited, and the developer is the owner of the island, who is also a resident of the island. Thus, it is easy to integrate all smart service systems as smart visiting management systems, with the key ID as a form of personal information is set up in order to connect all databases of smart services.

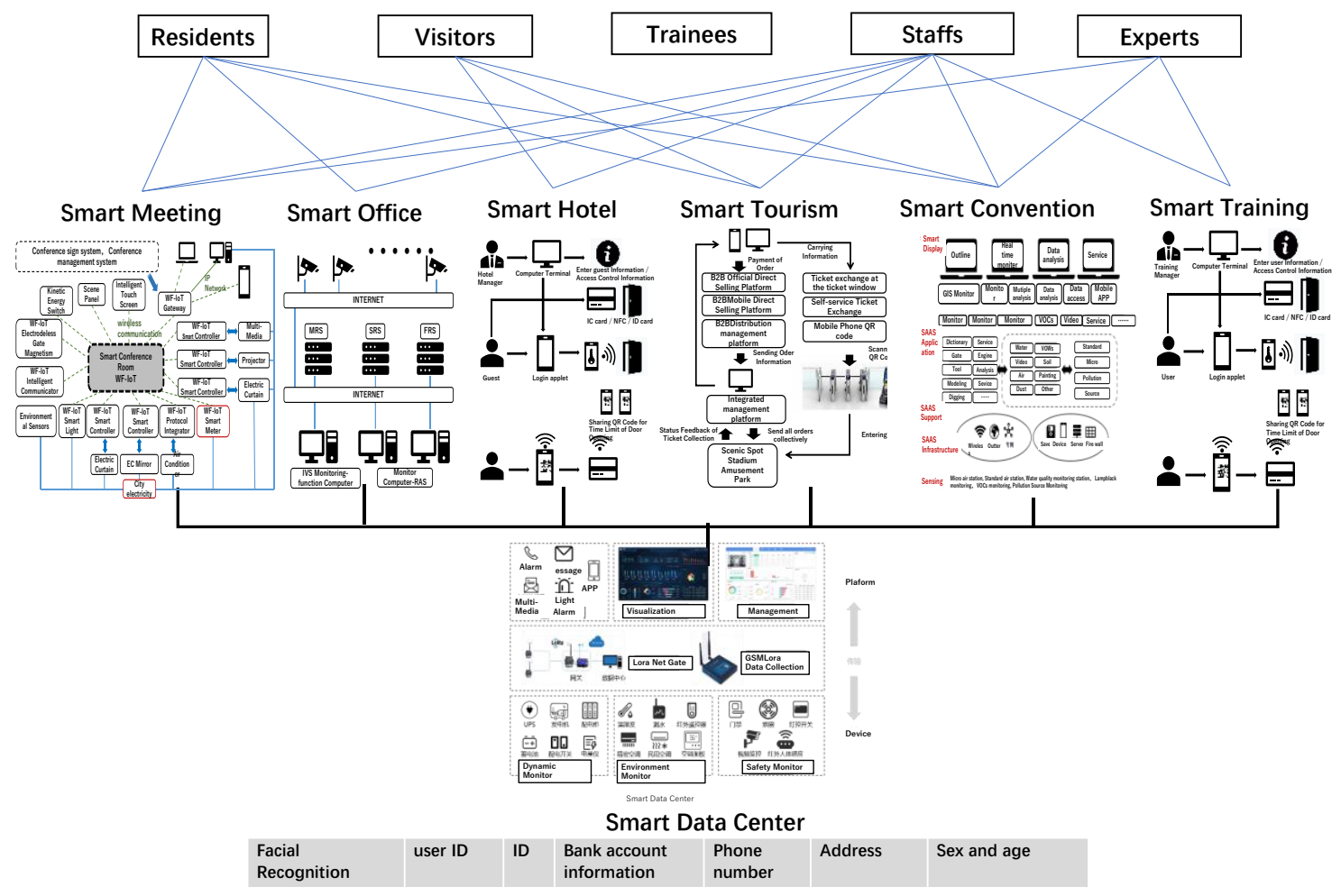

Figure 6. Personal information integrated in the SVSMS.

As for the personal information for the integrated visiting smart service management system, there are three types, described in the following sections.

\subsection{Public Personal Information}

Visitors or other users have to access smart service systems, thereby it is possible to ask them for cooperation in sharing their data for smart visiting management on the island. One of the possible cooperative tasks is sharing the personal information for security checking, hotel, and conference rooms, setting the time schedule between different smart service systems. In order to identify the 
correct person who needs the support from another service, it is necessary for the personal information to be shared in the servers of the integrated database. Meanwhile, personal information should be transferred between smart service systems in order to provide the correct relative smart service, due to different services being run by the different providers. Usernames and other necessary information, such as IDs, birthdays, and so on, which can be shared with different smart services systems, can be defined as public personal information. However, the kind of data that can be defined as public personal information depends on the kind of information that is needed between different systems.

\subsection{Non-Public Personal Information for Identification}

Services used by the people do not necessary need to be shared with other smart service systems; they can be saved in one smart service system. Moreover, payment information of each system should be recorded in the integrated database, to pay once, for all of the expenses on the island, after visiting. The total amount of payment to one service system can be sent to the integrated database, in order to calculate the total consumption on the island. It is not necessary to share the bank account information with all of the systems, if only one integrated payment system is used for visiting management, thereby, the users do not need to register their bank information in different service systems. In this case, the bank account information that belongs to the non-public personal information is not shared with different smart service systems.

\subsection{Non-Personal Information for Smart Services}

There are some products, such as automatic doors, water sensors in toilets, and automatic lighting, that are separated from smart service systems. Even these products are deployed in all building spaces, as indicated in Figure 7, and it is necessary to take the status data of these products for maintenance. However, there is no need to save the personal information of users in the integrated database. There are many smart devices that respond to each individual user, but it is not necessary to save their personal information. Furthermore, it is not fundamental to save it in any additional database. This kind of data without the personal information can be kept in the devices only.

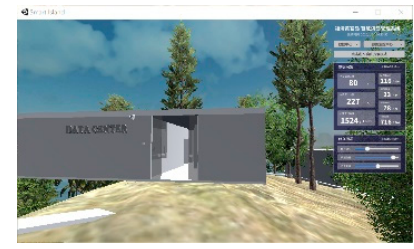

(a) Data center

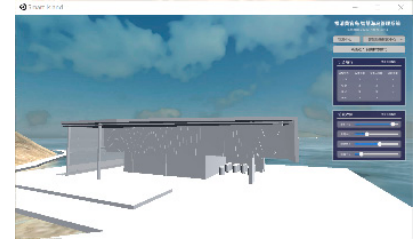

(d) Waste disposal center

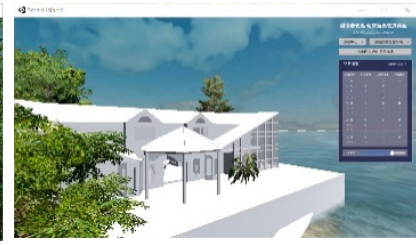

(b) Visitor center

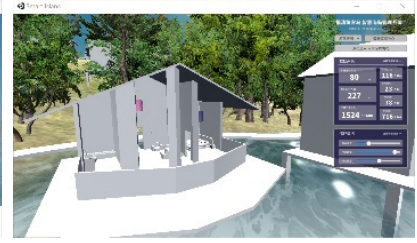

(e) Hotel

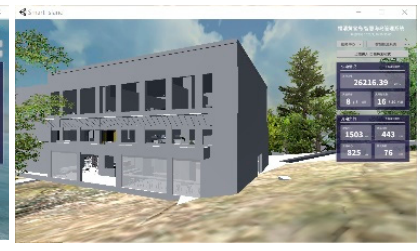

(c) Convention/conference center

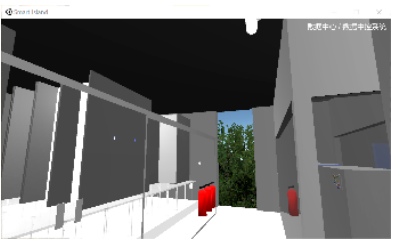

(f) Data storage space

Figure 7. SVSMS using virtual reality in Huangguan Island: (a) Data center; (b) Visitor center; (c) Convention/conference center; (d) Waste disposal center; (e) Hotel; (f) Data storage space.

\subsection{Principle of Personal Information Application on Huangguan Island}

Based on the discussion above, the principles of personal information application are demonstrated in Table 4. As a result, it is important to divide personal information into three types: non-public personal information, public personal information, and non-personal information. Firstly, let us consider the 
non-public personal information. Facial photos, IDs, and so on are made by the government, and can be used to identify the personality for security checking. Other private information, such as sex and birthday, address, phone number, bank account, and credit card information, are necessary for the service companies, in order to provide tourism services and collect service fees. All this information is related to the personal private information, thus, it does not need to be shared by the data center in the SVSMS. Secondly, when using the SVSMS, user names, IDs, and the services to which they applied, are important for their payments to smart services, and can be shared in the data center of the SVSMS. Finally, the infrastructure monitoring is not considered as the personal information, even when users use the smart infrastructure.

Table 4. Principles of personal information application for the smart visiting service management.

\begin{tabular}{|c|c|c|c|c|}
\hline Data Protection & $\begin{array}{c}\text { Personal } \\
\text { Information }\end{array}$ & $\begin{array}{c}\text { Smart Service } \\
\text { System Run by a } \\
\text { Service Company }\end{array}$ & $\begin{array}{l}\text { Data Center in } \\
\text { SVSMS Run by } \\
\text { Government }\end{array}$ & $\begin{array}{l}\text { Application of } \\
\text { Personal } \\
\text { Information }\end{array}$ \\
\hline \multirow{6}{*}{$\begin{array}{l}\text { Non-public } \\
\text { personal } \\
\text { information }\end{array}$} & Facial photo & $\begin{array}{l}\text { Scanned but not } \\
\text { saved }\end{array}$ & $\begin{array}{l}\text { Identified by } \\
\text { government } \\
\text { database }\end{array}$ & Security checking \\
\hline & ID & $\begin{array}{l}\text { Scanned but not } \\
\text { saved }\end{array}$ & $\begin{array}{l}\text { Identified by } \\
\text { government } \\
\text { database }\end{array}$ & Security checking \\
\hline & Sex and birthday & Saved exclusively & $\begin{array}{l}\text { Not shared with } \\
\text { data center }\end{array}$ & $\begin{array}{l}\text { Identification of } \\
\text { service user }\end{array}$ \\
\hline & Phone number & Saved exclusively & $\begin{array}{l}\text { Not shared with } \\
\text { data center }\end{array}$ & $\begin{array}{l}\text { Identification of } \\
\text { service user }\end{array}$ \\
\hline & Address & Saved exclusively & $\begin{array}{l}\text { Not shared with } \\
\text { data center }\end{array}$ & $\begin{array}{l}\text { Identification of } \\
\text { service user }\end{array}$ \\
\hline & $\begin{array}{c}\text { Bank account or } \\
\text { credit card } \\
\text { information }\end{array}$ & $\begin{array}{l}\text { Scanned but not } \\
\text { saved. (Identified } \\
\text { by bank or credit } \\
\text { card companies) }\end{array}$ & & Payment \\
\hline \multirow{3}{*}{$\begin{array}{l}\text { Public personal } \\
\text { information }\end{array}$} & Name & Shared & $\begin{array}{l}\text { Shared with } \\
\text { data center }\end{array}$ & $\begin{array}{c}\text { Identification of } \\
\text { service user }\end{array}$ \\
\hline & User ID & Shared & $\begin{array}{l}\text { Shared with } \\
\text { data center }\end{array}$ & $\begin{array}{l}\text { Calculation total } \\
\text { amount service fee }\end{array}$ \\
\hline & Services used & Shared & $\begin{array}{l}\text { Shared with } \\
\text { data center }\end{array}$ & $\begin{array}{l}\text { Calculation total } \\
\text { amount service fee }\end{array}$ \\
\hline \multirow{4}{*}{\multicolumn{2}{|c|}{ Non-personal information }} & Productions & $\begin{array}{l}\text { Data center in } \\
\text { SVSMS }\end{array}$ & \\
\hline & & Light sensor & No recorded data & \\
\hline & & Door sensor & No recorded data & \\
\hline & & Others & & \\
\hline
\end{tabular}

\section{Conclusions}

Previous works [5] are focused on the development of different kinds of tourism information services for tourism organizations, and claim that by using big data analysis and processing means, researchers can improve practices in tourism businesses and serve tourists better. In this paper, we proposed a management system using virtual reality for tourism services, and took the Huangguan smart island project as a case study in order to figure out how to design the visiting service system in the island space, and how to collect personal information for smart visiting service management.

We suggest the infrastructure monitoring system and the smart service system for smart visiting management on the island. Personal information collected in the island space is a relatively small 
database that can be organized in one integrated database in this system; it is also easy to integrate the database of smart services as one visiting management system for cooperation between the service providers. Personal information collected in the island space is complicated, due to different service providers collecting different personal data for various business purposes. Personal information is collected by the sensors not only in personal mobile devices, but also in smart LoT facilities deployed in the buildings of the urban space. Thus, the smart visiting service management system is able to share the personal information for integration of all separated smart visiting services.

Finally, we discuss the principles of personal information collection. The personal information is supplied by different providers, which usually makes it impossible to share this information between them, thus, it is unreasonable to identify an individual person for protection of non-public personal information, if there is no integrated database. Besides the non-public personal information, public personal information can be shared between smart service systems, and there is also a kind of smart device that will not collect personal information. As a result, we can divide personal information into three types: public, non-public personal information, and non-personal information.

Different smart services require different types of personal information, so it is important to organize smart devices in building spaces. In further research, we investigate what kind of personal information is necessary for different types of smart services, and then we can further discuss the standards of planning and design for smart devices in the smart city constructions.

Author Contributions: Z.S. conceived and designed the research; X.T. and Z.S. wrote the original manuscript. All authors have read and agreed to the published version of the manuscript.

Funding: This research was funded by JSPS Grant-in-Aid for Scientific Research (C), project 18K04523 and 19K04750.

Acknowledgments: The virtual reality environment is created by a student team of Joint Lab SPSD of Fuzhou University-Kanazawa University.

Conflicts of Interest: The authors declare no conflict of interest.

\section{References}

1. Zhao, Y.; Tarus, S.K.; Yang, L.T.; Sun, J.; Wang, J. Privacy-preserving clustering for big data in cyber-physicalsocial systems: Survey and perspectives. Inf. Sci. 2020, 515, 132-155. [CrossRef]

2. Bibri, S.E. The IoT for smart sustainable cities of the future: An analytical framework for sensor-based big data applications for environmental sustainability. Sustain. Cities Soc. 2018, 38, 230-253. [CrossRef]

3. Liu, L.; Gao, X.; Zhuang, J.; Wu, W.; Deng, O. Evaluating the lifestyle impact of China's rural housing land consolidation with locational big data: A study of Chengdu. Land Use Policy 2020, 96, 104623. [CrossRef]

4. Yang, P.P.J.; Yamagata, Y. Urban systems design: Shaping smart cities by integrating urban design and systems science. In Urban Systems Design; Elsevier: Amsterdam, The Netherlands, 2020; pp. 1-22. [CrossRef]

5. Li, Y.; Hu, C.; Huang, C.; Duan, L. The concept of smart tourism in the context of tourism information services. Tour. Manag. 2017, 58, 293-300. [CrossRef]

6. Babar, M.; Arif, F.; Jan, M.A.; Tan, Z.; Khan, F. Urban data management system: Towards Big Data analytics for Internet of Things based smart urban environment using customized Hadoop. Future Gener. Comput. Syst. 2019, 96, 398-409. [CrossRef]

7. Dong, J.Q.; Yang, C.H. Business value of big data analytics: A systems-theoretic approach and empirical test. Inf. Manag. 2020, 57, 103124. [CrossRef]

8. Long, Y.; Enjia, Z. Data Augmented Design—Embracing New Data for Sustainable Urban Planning and Design. In Series Spatial Planning and Sustainable Development; Zhenjiang, S., Ed.; Springer: Berlin/Heidelberg, Germany, 2020; Available online: https://www.springer.com/jp/book/9783030496173 (accessed on 15 September 2020).

9. Andreani, S.; Kalchschmidt, M.; Pinto, R.; Sayegh, A. Reframing technologically enhanced urban scenarios: A design research model towards human centered smart cities. Technol. Forecast. Soc. Chang. 2019, 142, 15-25. [CrossRef]

10. Kontogianni, A.; Alepis, E. Smart tourism: State of the art and literature review for the last six years. Array 2020, 6, 100020. [CrossRef] 
11. Lin, Y.; Teng, X.; Shen, Z. Reviewing on Personal Information Protection. In Proceedings of the Age of Big Date, International Conference on Spatial Planning and Sustainable Development, Chiba, Japan, 31 July-2 August 2019.

12. Teng, X.; Shen, Z.; Lin, Y. Evaluation on Improvement of Education Quality using Personal Information in Smart Education System. In Proceedings of the 2nd Asian Forum of Science and Technology, Beijing, China, 16 November 2019.

13. Anrong, D.; Li, G.; Li, J.; Xianjuan, K. Research on Smart Community Planning of Yishanwan, China towards New Urbanization. Int. Rev. Spat. Plan. Sustain. Dev. 2016, 4, 78-90. [CrossRef]

14. Das, D.K. Exploring the Politico-Cultural Dimensions for Development of Smart Cities in India. Int. Rev. Spat. Plan. Sustain. Dev. 2019, 5, 79-99. [CrossRef]

15. Wang, T.; Duong, T.D.; Chen, C.C. Intention to disclose personal information via mobile applications: A privacy calculus perspective. Int. J. Inf. Manag. 2016, 36, 531-542. [CrossRef]

16. Das, A.; Sharma, S.C.M.; Ratha, B.K. The New Era of Smart Cities, From the Perspective of the Internet of Things. In Smart Cities Cyber Security and Privacy; Elsevier: Amsterdam, The Netherlands, 2019; pp. 1-9. [CrossRef]

17. Brdys, M.A. Intelligent monitoring and control for critical infrastructure systems and application to integrated wastewater treatment systems. IFAC Proc. 2010, 43, 2-12. [CrossRef]

18. Kane, M.B.; Peckens, C.; Lynch, J.P. Design and selection of wireless structural monitoring systems for civil infrastructures. In Sensor Technologies for Civil Infrastructures; Wang, M., Lynch, J., Sohn, H., Eds.; Elsevier: Amsterdam, The Netherlands, 2014; pp. 446-479. [CrossRef]

19. Shen, Z. Geospatial Techniques in Urban Planning; Springer: Berlin/Heidelberg, Germany, 2012.

20. Kim, D.; Park, K.; Park, Y.; Ahn, J.A. Willingness to provide personal information: Perspective of privacy calculus in IoT services. Comput. Hum. Behav. 2019, 92, 273-281. [CrossRef]

21. Widjaja, A.E.; Chen, J.V.; Sukoco, B.M.; Ha, Q. Understanding users' willingness to put their personal information on the personal cloud-based storage applications: An empirical study. Comput. Hum. Behav. 2019, 91, 167-185. [CrossRef]

22. Vandercruysse, L.; Buts, C.; Dooms, M. A typology of Smart City services: The case of Data Protection Impact Assessment. Cities 2020, 104, 102731. [CrossRef]

23. Edler, D.; Keil, J.; Wiedenlübbert, T.; Sossna, M.; Kühne, O.; Dickmann, F. Immersive VR Experience of Redeveloped Post-Industrial Sites: The Example of "Zeche Holland" in Bochum-Wattenscheid. KN J. Cartogr. Geogr. Inf. 2019, 69, 267-284. [CrossRef]

24. Büyüksalih, G.; Kan, T.; Özkan, G.E.; Meriç, M.; Isýn, L.; Kersten, T. Preserving the Knowledge of the Past Through Virtual Visits: From 3D Laser Scanning to Virtual Reality Visualisation at the Istanbul Çatalca İnceğiz Caves. PFG J. Photogramm. Remote Sens. Geoinf. Sci. 2020, 88, 133-146. [CrossRef] 